Article

\title{
Adoption and Development of the Fourth Industrial Revolution Technology: Features and Determinants
}

\author{
Hyuk Chung (1)
}

check for updates

Citation: Chung, H. Adoption and Development of the Fourth Industrial Revolution Technology: Features and Determinants. Sustainability 2021, 13, 871. https://doi.org/10.3390/su130 20871

Received: 7 December 2020

Accepted: 14 January 2021

Published: 16 January 2021

Publisher's Note: MDPI stays neutral with regard to jurisdictional claims in published maps and institutional affiliations.

Copyright: (C) 2021 by the author. Licensee MDPI, Basel, Switzerland. This article is an open access article distributed under the terms and conditions of the Creative Commons Attribution (CC BY) license (https:/ / creativecommons.org/licenses/by/ $4.0 /)$.
School of Economics, Chung-Ang University, Seoul 06724, Korea; hchungecon@cau.ac.kr

\begin{abstract}
Firms have been undergoing a fundamental transformation of the Fourth Industrial Revolution, and the transformation is driven by the adoption and development of innovative technology such as big data or artificial intelligence. While the impacts of the Fourth Industrial Revolution technology on economic performance have been actively documented, Korean firm-level data indicates that still, the majority of firms have not yet utilized the Fourth Industrial Revolution technology. Hence, this study examines determinants and propensity for adopting and developing the Fourth Industrial Revolution technology. Probit model estimations show that size, internal R\&D intensity, the ratio of intangible assets to the sum of intangible and tangible assets, and patent rights are positively associated with adopting and developing the innovative technology, while there are sectoral differences. Notably, a strategic alliance is the most substantial factor for the propensity of adopting and developing the Fourth Industrial Revolution technology. In sum, this study finds that not only internally accumulated intangibles and R\&D investment but also active collaboration with other firms can facilitate diffusion of the Fourth Industrial Revolution technology. Therefore, building up the environment to prompt collaboration can be another effective way to accelerate transformation in addition to supporting R\&D and intangible investment.
\end{abstract}

Keywords: fourth industrial revolution; technology adoption; technology development; probit

\section{Introduction}

After the initiative of "Industry 4.0 " to promote digitization of manufacturing was launched by the German government in 2011 [1], the term "Fourth Industrial Revolution" was introduced to the public by Schwab [2]. Since then, the Fourth Industrial Revolution, along with Industry 4.0, has become the main keyword of structural transformation around the world. For the decade since the introduction of Industry 4.0, industry and firms have recognized technological change, innovation, and human capital as the main driver of the transformation of the economy and society. However, at the same time, the degree of readiness for the industrial revolution has varied across countries [3].

Among countries, Korea faces a unique challenge under this circumstance. At least from the traditional perspective of innovative inputs, the Korean economy has successfully escalated research and development $(R \& D)$ efforts, measured as the ratio of R\&D expenditures to gross domestic product (GDP), reaching the highest level among Organization for Economic Cooperation and Development (OECD) countries (Korea 4.5\%, OECD total 2.4\% in 2018) (source: OECD data, link: https: / / data.oecd.org/rd/gross-domestic-spending-onr-d.htm). The share of investment in intellectual property products also has consistently increased (Figure 1). However, intensifying innovative investment had not resulted in sustained growth, as the GDP growth rate had not exceeded $4 \%$ since the short-lived bounce-back in 2010 when it reached 6.7\% (Figure 2). Therefore, it is imperative to find another initiative for innovation in response to the Fourth Industrial Revolution. 


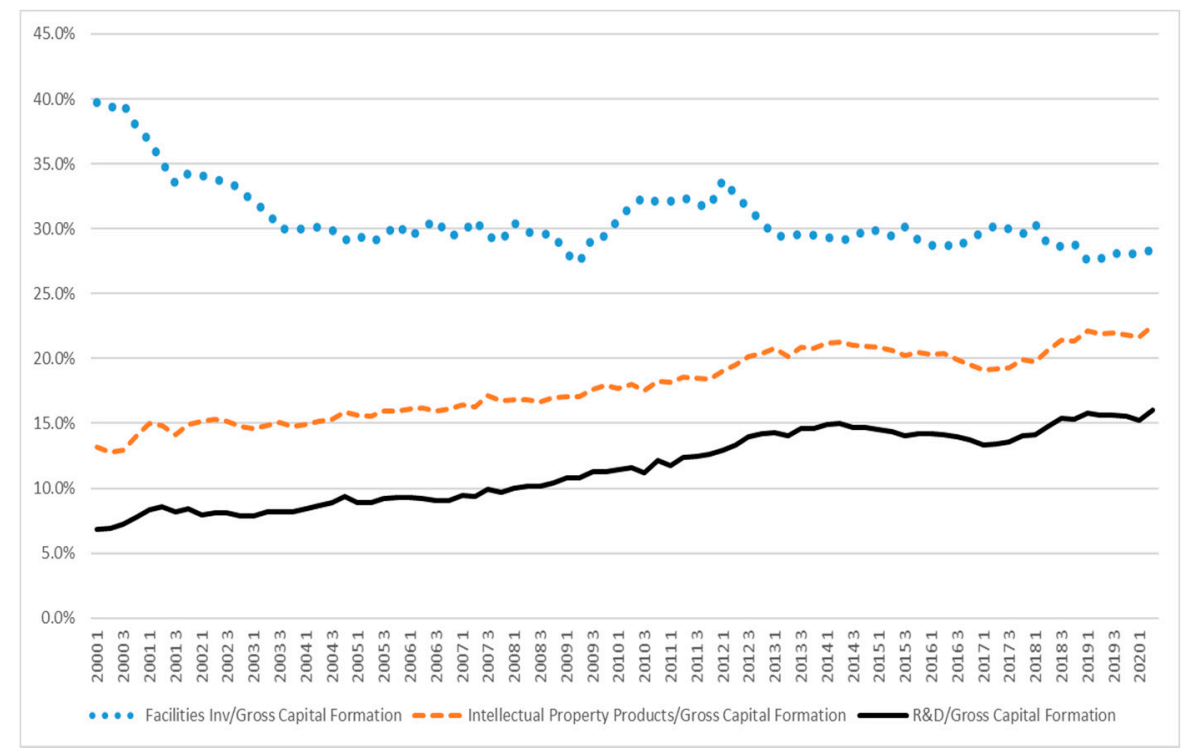

Figure 1. Ratio of facilities, intellectual property products, and research and development (R\&D) investment to gross capital formation using quarterly data. R\&D investment is included in intellectual property products investment. Data: Bank of Korea Economic Statistics System (source: https: / / ecos.bok.or.kr, downloaded 6 November 2020).

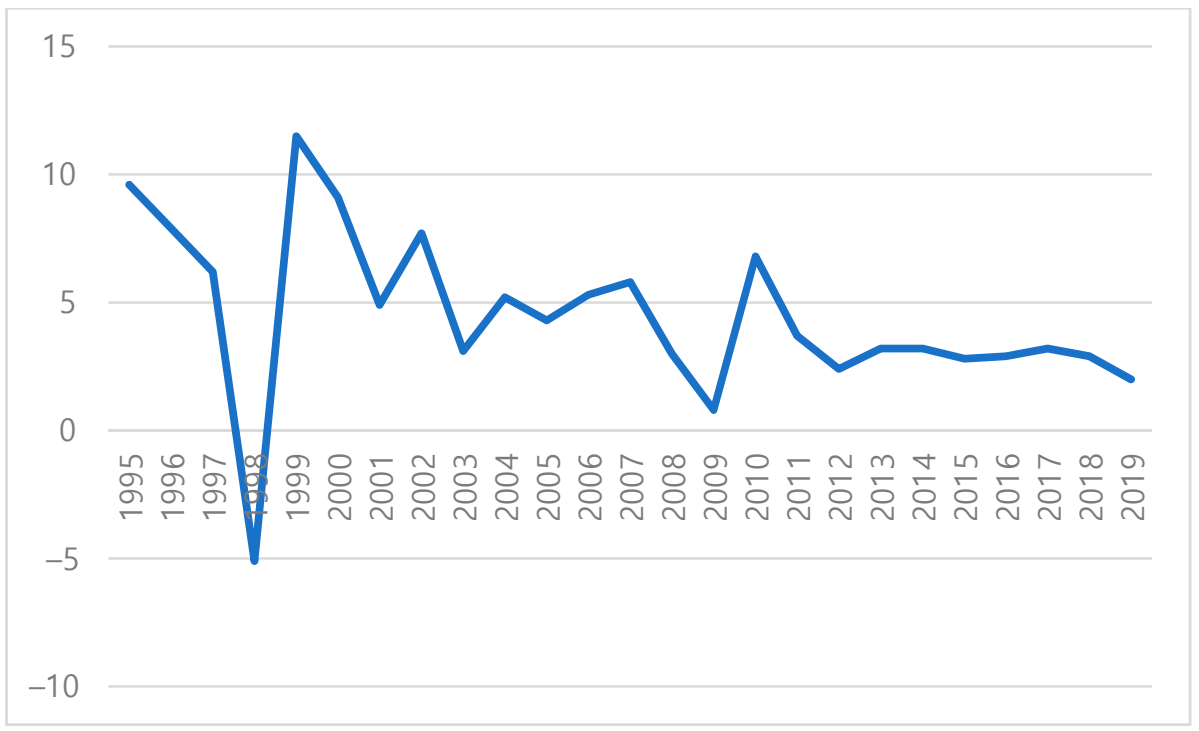

Figure 2. GDP growth rate of Korea. Data: Bank of Korea Economic Statistics System (source: https:/ / ecos.bok.or.kr, downloaded 17 December 2020).

On the other hand, Korea has been nominated as a top innovative country by Bloomberg for years [4]. A report by Tufts University ranks Korea 7th most digitalized country among 60 countries [5]. Korean high rankings are driven by high R\&D intensity, a high share of an educated workforce, and strong Internet infrastructure. However, overall readiness for the future surveyed by the World Economic Forum is mediocre [3]. For instance, the ranking of technology and innovation as a future driver is the only 17th. Global Innovation Index 2020 listed Korea as the 10th most innovative country among 131 countries, but Korea lags in the political environment (24th) and regulatory environment (52nd) [6]. The disparity suggests that the Korean economy needs to improve qualitative aspects of innovation such as institutional reform beyond simply increasing innovative inputs if it wants to successfully respond to the undergoing industrial revolution [7]. 
To investigate the actual readiness to the industrial revolution of an economy under the circumstance like Korea, firm-level analysis can be helpful. How have firms responded to the transformation of the Fourth Industrial Revolution? One direct measure of firmlevel response to the Fourth Industrial Revolution would be the adoption of innovative technology such as artificial intelligence. According to the Survey of Business Activities, a firm-level data in Korea, not many firms have not adopted or developed any Fourth Industrial Revolution technology, as we will see in Section 3. Given this background, this study aims to investigate firm-level determinants of adoption and development of the Fourth Industrial Revolution technology at the firm-level.

This study applies probit estimation to analyze the propensity of adoption and development of the Fourth Industrial Revolution technology. Data from the Survey of Business Activities is used since it includes a questionnaire on the Fourth Industrial Revolution technology, and the survey in 2018 was the first national firm-level survey on the overall status of the Fourth Industrial Revolution technology. The survey asked firms whether they adopted or developed innovative technology, such as the Internet of things (IoT), cloud computing, big data, fifth-generation mobile technology (5G), artificial intelligence (AI), blockchain, 3D printing, robotics, or virtual/augmented reality (AR/VR). Since the database includes information on firm-specific characteristics such as size and ownership structure, it can help investigate firm-specific determinants of the Fourth Industrial Revolution technology.

The main findings can be summarized as follows: in the manufacturing sector, size, internal R\&D intensity, the ratio of intangible assets to the sum of intangible and tangible assets, and patent and trademark rights are positively associated with the propensity for adopting and developing technology; in the service sector, size, the intangible assets ratio, and patent rights are positive factors of this propensity. A strategic alliance is a common significant factor for the adoption and development of the Fourth Industrial Revolution technology. The result of a strategic alliance emphasizes the importance of collaboration with external agents to diffuse the innovative technology, which could mitigate limited internal capability.

The rest of the paper is organized as follows: In Section 2, the literature related to the Fourth Industrial Revolution and determinants of innovative investment is reviewed. Section 3 includes data descriptions, model construction, and empirical analysis. Section 4 presents a summary of the empirical results, and the final section discusses the implications for further research.

\section{Literature Review}

Following the Third Industrial Revolution based on computerization and automation, the Fourth Industrial Revolution can be defined as the development of a "cyber-physical system". Prior to the World Economic Forum in 2016, "Industry 4.0" had been introduced as a strategy to innovate manufacturing in Germany by developing the cyber-physical system, which integrates the production process with digital technology [8]. The idea is reflected in the smart factory, which relies on the Internet of things (IoT), data, and artificial intelligence (AI). By actively using artificial intelligence and data collected by IoT, all processes of production, from planning to maintenance, can be more productive and cost-efficient [9].

While Industry 4.0 focuses on manufacturing, the Fourth Industrial Revolution era involves a broader area with cyber-physical systems of hardware, software and even biology that should improve the capabilities of people and machines $[2,10]$. The Fourth Industrial Revolution is characterized as the transformation to a society with hyper-connectivity, hyper-intelligence, and convergence [11]. It is considered that unprecedented speed, scope and depth, and systematic impacts of transformation make the Fourth Industrial Revolution fundamentally different from the Third Industrial Revolution [2].

Specifically, IoT, cloud computing, big data, 5G, AI, 3D printing, robotics, and AR/VR are considered to play central roles in the Fourth Industrial Revolution. IoT connects things 
and humans in both of physical world and virtual area, and it collects a huge volume of data from everything. Thus, IoT enables manufacturers to monitor products in real time and provide personalized services in time [12]. Cloud computing expands the capability of software and allows artificial intelligence and robotics to operate on the platform in cloud computing [11]. Big data technology analyzes large-scale data, including informal information as voice and images, thus enables to extract valuable information from the data. Then rapid development of AI with machine learning, artificial neural network, and deep learning will allow the automation of production and personalized services without the intervention of human beings [11,13]. Behind these technologies, 5G wireless technologies are essential to process all information collected from devices and allow smooth communications in real time. This leads to the development of automation, digitization, and servicification [11,12]. On the other hand, 3D printing also has the potential to change manufacturing by utilizing novel materials and printing multi-material objects, while it is also expected to contribute to the sustainable use of non-plastic materials [14]. Finally, AR/VR technology can provide users experience involving both online and offline [11]. When devices and machines can communicate autonomously with the help of developed censors, IoT, big data, and AI, robotics will fundamentally transform the production process of manufacturing, but also the quality of services [14]. Based on the rapid progress of information and communication technology (ICT), a large part of manual and cognitive work by humans has been replaced by machines, and there may be more to come [15]. In summary, the Fourth Industrial Revolution technology has the potential to transform various kinds of businesses, not limited to manufacturing [16]. Eventually, the innovative technology will cause widespread and profound impacts on every aspect of society $[2,17]$.

Furthermore, the Fourth Industrial Revolution is predicted to have enormous macroeconomic impacts since innovative investment can improve productivity and income growth For instance, Chen et al. [18] forecasted that $\mathrm{AI}^{\prime} \mathrm{s}$ economic impact could range from $\$ 359.6$ billion to $\$ 773.2$ billion, or even from $\$ 1.49$ trillion to $\$ 2.95$ trillion between 2016 and 2025 , based on a different set of benchmark approach. Accordingly, governments of major countries have launched various strategies to maximize benefits from the revolutionary changes [19].

The emergence of the Fourth Industrial Revolution inevitably necessitates investment, and ICT investment has already been studied well [20,21]. Oulton [20] and Colecchia and Schreyer [21] showed there was direct productivity improvement by adopting productive ICT capital, whereas Corrado, Haskel, and Jona-Lasinio [22] emphasized the complementarity of ICT and intangible capital. The latter implies not only ICT production but also productive ICT usage has substantial effects on knowledge accumulation. It indicates that developing or using the Fourth Industrial Revolution technology may have a positive influence on knowledge accumulation. At the aggregate level, ICT investment is found to be facilitated by changes in market regulation, increases in human capital, more R\&D expenditure, and a larger share of the dynamic services sector [23]. At the firm level, larger, younger, fast-growing, skill-intensive, export-intensive, and urban firms are found to be successful in adopting and using ICT [24].

$\mathrm{R} \& \mathrm{D}$ and intangible investment are also innovative investments, and endogenous growth theory shows that innovative investment can lead to sustained growth with higher productivity growth $[25,26]$. R\&D and intangible investment have been recognized as significant sources of economic growth [27-30]. Firm-level studies have found that intangible capital accumulation contributes to firm value, productivity, and growth [31-33]. Many empirical studies on determinants of the Fourth Industrial Revolution technology is yet to come, but the studies on determinants on R\&D and intangible investment can be a useful reference. Studies on firm-level determinants of innovative investment have found significant firm heterogeneity in terms of firm size, human capital, and past intangible capital accumulation explaining the propensity for intangible investment [34]. Firm size is likely to positively affect the tendency to invest in intangible capital [34] and R\&D [35]. Larger firms have an advantage in economies of scale and larger internal financial resources 
for innovative but risky investments [36]. Another determinant is the capability to adapt and develop the technology. Arrighetti et al. [34] showed that firms with a more educated workforce or R\&D capability are more capable of investing in intangible capital. A larger intangible asset base also implies better innovation capability of the organization [35].

Furthermore, intangibles involve organizational capital, as the effectiveness of ICT is maximized when ICT adoption is accompanied by organizational change [37]. On the other hand, organizational capital is a significant factor in intangible capital accumulation $[34,38]$. The organizational capability of a firm can be expanded by external relation to overcoming limited internal resources. R\&D cooperation can contribute to knowledge spillover and efficient allocation of R\&D resources by utilizing external resources and adapting the internal organization accordingly $[39,40]$. R\&D cooperation can result in firm performance, such as market acceptance. However, such an effect may be limited to larger firms [41], whereas firm performance may depend on the characteristics of an R\&D cooperation partner [42]. Moreover, the strategical alliance also can contribute to technological knowledge transfer $[43,44]$, and the choice of alliance partners can make a difference in performance [45]. Therefore, it is plausible to observe similar effects of organizational factors on investment in the Fourth Industrial Revolution technology.

Finally, financial constraints have been considered as a major factor in R\&D investment [46-48]. Financing R\&D investment is mainly dependent on internal cash flow, and equity finance is more favorable than debt finance due to asymmetric information $[49,50]$. This feature is evident in the growth of the R\&D-intensive sector during the 1990s boom in the United States [51], and the effects of financial constraints are different between routine and cutting-edge R\&D investment [52]. Thus, it is possible that financial condition affects technological decisions amid the Fourth Industrial Revolution.

\section{Methods}

\subsection{Data and Descriptive Statistics}

\subsubsection{Data}

The Survey of Business Activities is conducted annually by the Korean government statistics agency. It includes firms with more than 50 employees and capital of more than 300 million Korean won, but also service firms with a capital of more than 1000 million Korean won and fewer than 50 employees. The data were acquired through the Korean government official data platform, named Microdata Integrated Service (MDIS).

The data provide information on firm size, assets, investments, intellectual property rights, basic corporate finance, and organizational features such as parent/subsidiary. The survey in 2018 added a questionnaire on the status of adopting and developing the Fourth Industrial Revolution technologies, including IoT, cloud computing, big data, 5G wireless technologies, AI, blockchain, 3D printing, robotics, and AR/VR. Thus, the data provides broad information on the status of the Fourth Industrial Revolution in the Korean economy. Due to the limited sample of the data, this study may not be representative, but it enables to utilize a rich set of firm-specific information that is not available at the macro level.

Variables for the analysis were the indicator variables of adoption and development of the Fourth Industrial Revolution technology, the existence of parent/subsidiary company, and strategic alliance with other firms. Employment, tangible and intangible assets, R\&D investment, number of intellectual property rights for each type (patents and trademarks), and corporate financial information such as debt ratio and profitability were added as firm-specific control variables.

\subsubsection{Descriptive Statistics}

Figures 3 and 4 show the sums of positive responses to the question of whether a firm has adopted or developed any Fourth Industrial Revolution technologies at the two-digit industry code level for the manufacturing and service sectors, respectively. Figure 3 shows that manufacturers of electronics (industry code 26), other machinery and equipment (industry code 29), and motor vehicles and trailers (industry code 30) are active in adopting 
and developing such technology. Figure 4 shows that firms in publishing activities (industry code 58) and computer programming (industry code 60) have actively adopted and/or developed such technology. These figures indicate the existence of sectoral heterogeneity in the degree of technology adoption.

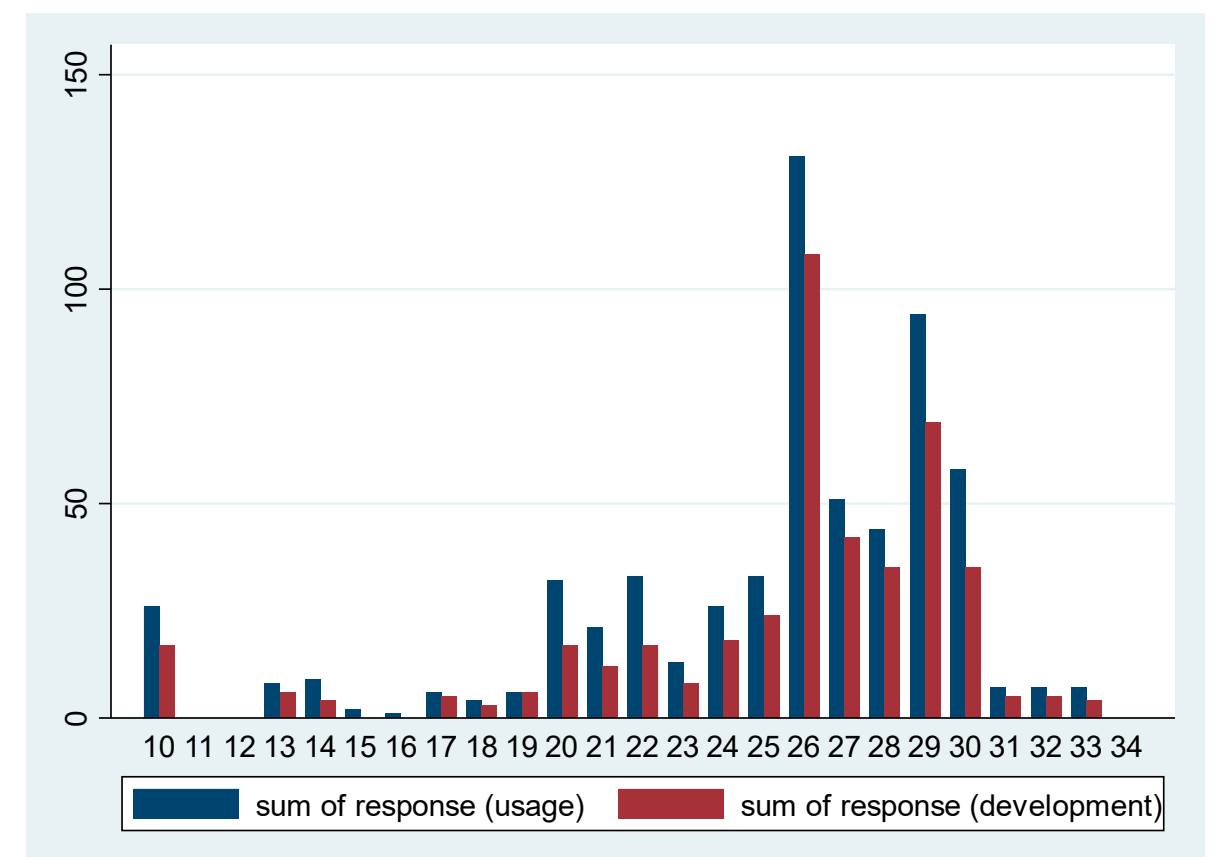

Figure 3. Industry-level sum of responses on adoption and development of Fourth Industrial Revolution technologies (manufacturing sector).

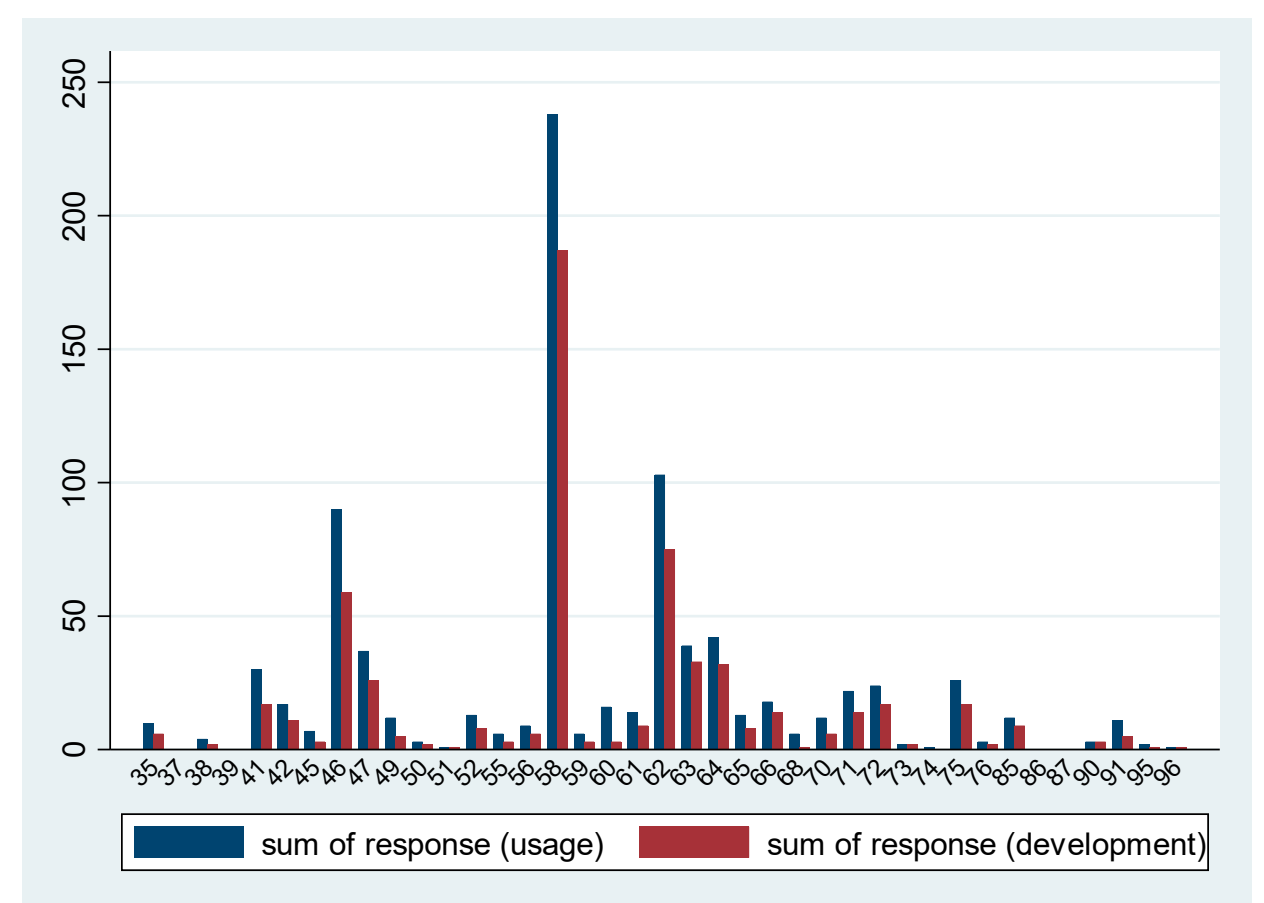

Figure 4. Industry-level sum of responses on adoption and development of Fourth Industrial Revolution technologies (service sector).

Descriptive statistics are presented in Table 1. Binary indicator variables include adoption and development of at least one of the mentioned technologies (IoT, cloud 
computing, big data, 5G, AI, blockchain, 3D printing, robotics, and AR/VR). Other binary indicator variables are the existence of parent companies and subsidiaries and any strategic alliances with other firms.

Table 1. Descriptive statistics.

\begin{tabular}{|c|c|c|c|c|c|c|}
\hline & \multirow[b]{2}{*}{ No. Obs } & \multicolumn{2}{|c|}{ Manufacturing } & \multicolumn{3}{|c|}{ Service } \\
\hline & & Mean & Std. Dev. & No. Obs & Mean & Std. Dev. \\
\hline Adoption ${ }^{1}$ & 6162 & 0.10 & - & 6599 & 0.13 & - \\
\hline Development ${ }^{1}$ & 6288 & 0.07 & - & 6813 & 0.09 & - \\
\hline Employment & 6162 & 296.8 & 1928.6 & 6599 & 331.8 & 1104.2 \\
\hline Internal R\&D intensity & 6161 & 0.02 & 0.07 & 6584 & 0.09 & 3.25 \\
\hline Intangible assets ratio & 6159 & 0.05 & 0.11 & 6583 & 0.16 & 0.27 \\
\hline Patents & 6162 & 47.0 & 662 & 6599 & 7.7 & 86.8 \\
\hline Trademarks & 6162 & 29.0 & 268 & 6599 & 19.7 & 115.0 \\
\hline Permanent employee ratio & 6162 & 0.99 & 0.06 & 6599 & 0.93 & 0.18 \\
\hline Outsourcing ratio & 6161 & 0.08 & 0.17 & 6584 & 0.08 & 0.34 \\
\hline External R\&D intensity & 6161 & 0.00 & 0.02 & 6584 & 0.01 & 0.71 \\
\hline Parent company ${ }^{1}$ & 6162 & 0.19 & - & 6599 & 0.30 & - \\
\hline Subsidiary ${ }^{1}$ & 6162 & 0.49 & - & 6599 & 0.39 & - \\
\hline Strategic alliance $^{1}$ & 6162 & 0.07 & - & 6599 & 0.07 & - \\
\hline Foreigners' share & 6162 & 0.09 & 0.26 & 6599 & 0.11 & 0.30 \\
\hline Profitability $^{2}$ & 6161 & 0.02 & 0.18 & 6584 & -0.28 & 11.00 \\
\hline Debt ratio 2 & 6162 & 0.52 & 0.34 & 6599 & 0.59 & 0.92 \\
\hline
\end{tabular}

${ }^{1}$ Binary indicator variables. For example, if the value of adoption (development) is 1, it means the respondent has adopted and used (self-developed) Fourth Industrial Revolution technology. Similarly, if a firm responds that it has a parent company (or subsidiary), then the binary variable parent company (subsidiary) is 1 , and 0 otherwise. ${ }^{2}$ Profitability is defined as the ratio of operating profit to sales, and debt ratio is defined as the ratio of total debt to total assets.

About 10 percent of firms have adopted any one of the Fourth Industrial Revolution technologies and, but less than 10 percent of firms have self-developed the technologies. Adoption and development ratios are higher for service than manufacturing firms. The average size measured by employment is larger for service than manufacturing firms as well.

The means of internal and external R\&D intensity, defined as the ratios of internal and external R\&D expenditures to sales, are lower for manufacturing firms than service firms, but in fact, the R\&D expenditure scale itself is much larger for manufacturing firms, particularly high-tech firms. Thus, the higher average internal and external R\&D intensity is likely to be driven by the smaller sales of service firms. On the other hand, the ratio of intangible assets to the sum of intangible and tangible assets is higher for service firms than manufacturing firms. The numbers of intellectual property rights, such as patents and trademarks, are larger for manufacturing firms. However, within sectors, manufacturing firms own more patents than trademarks, but service firms own more trademarks than patents.

The permanent employee ratio is lower in the service sector, implying the sector hires relatively more temporary workers. Service firms in the survey are more likely to be affiliated with a parent company, whereas manufacturing firms in the survey tend to have subsidiaries. Service firms in the sample are more likely to have a parent company than manufacturing firms while manufacturing firms are more likely to have subsidiaries than service firms. Moreover, there is no difference in the ratio of firms having strategic alliances with other firms.

\subsection{Empirical Model}

Firm size is measured by the number of employees, while the firm age is not used due to the lack of data. Since the composition of the workforce based on education level is not available from the data, internal R\&D intensity, defined as a ratio of internal R\&D expenditures to sales, is the variable representing a firm's capability of adopting or developing Fourth Industrial Revolution technologies. In contrast, external R\&D intensity 
could reflect a lack of the required internal resources for innovative investment. At the same time, it could mean the degree of R\&D collaboration with external organizations.

Furthermore, the ratio of intangible assets to the sum of intangible and tangible assets and the numbers of patent rights and trademark rights are included in the model as variables of cumulative dynamics. A higher ratio of intangible assets indicates that a firm is more inclined to invest in intangibles and be open to innovative knowledge. The numbers and types of intellectual property rights would reflect past paths of intangible capital accumulation, which will affect current decisions on technology adoption and development.

Organizational complexity is represented by labor flexibility within a firm, a degree of R\&D outsourcing, potential management complexity associated with affiliations, and strategic alliances. Therefore, the organizational complexity variables in this study are the ratio of permanent employees, external R\&D intensity, and indicator variables of the existence of affiliated firms (parent and/or subsidiary), foreigners' capital investment share, and strategic alliances.

Finally, financial conditions can affect the decision to adopt and/or develop the Fourth Industrial Revolution technologies. Based on the availability of data, this study uses profitability and debt ratio as the financial condition variables. Profitability is defined as the ratio of operating profit to sales, whereas the debt ratio is defined as the ratio of total liabilities to total assets.

To estimate the propensity (and developing) the Fourth Industrial Revolution technology, the model is as follows:

$$
y_{i}=f\left(X_{i}, \operatorname{Ind}_{i, j}, \varepsilon_{i}\right), \varepsilon_{i} \sim N\left(0, \sigma^{2}\right)
$$

where $y_{i}$ denotes a dichotomic variable taking the value one if the firm $i$ adopts (develops) the technology and zero otherwise, $X_{i}$ represents firm-specific characteristics such as R\&D intensity or affiliation; $I n d_{i, j}$ represents the industry $j$ to which firm $i$ belongs; and $\varepsilon_{i}$ is an idiosyncratic independent error with zero means and variance of $\sigma^{2}$. The model is estimated by the probit method, which estimates the equation, $\operatorname{Pr}\left[y_{i}=1\right]=\Phi\left(X_{i} \beta\right) . \Phi(\cdot)$ is the cumulative distribution function of the standard normal distribution. The parameter $(\beta)$ is estimated by maximum-likelihood estimation.

\subsection{Results}

Table 2 displays marginal effects from the probit estimation for the model. The first two columns show the estimation of adopting the Fourth Industrial Revolution technology for manufacturing and service sector firms. In both sectors, firm size positively affects the probability of adopting advanced technology. From the perspective of capability and cumulative dynamics, internal $R \& D$ intensity, intangible assets ratio, and intellectual property rights are all substantial factors contributing to the adoption of technology in manufacturing. However, only the intangible assets ratio and patent rights positively contribute to adoption in the service sector. In sum, the estimation results so far are summarized as follows: manufacturing firms with R\&D capability, large intangible assets and intellectual property rights are more likely to adopt the Fourth Industrial Revolution technology; service firms with more intangible assets and patent rights are strongly associated with technology adoption. 
Table 2. Probit estimation of marginal effects: manufacturing and service sectors.

\begin{tabular}{|c|c|c|c|c|}
\hline & \multicolumn{2}{|c|}{ Adoption } & \multicolumn{2}{|c|}{ Development } \\
\hline & (1) & (2) & (3) & (4) \\
\hline & Manufacturing & Service & Manufacturing & Service \\
\hline \multirow[t]{2}{*}{ Log(employment) } & $0.0278^{* * *}$ & $0.0266^{* * *}$ & $0.0195^{* * *}$ & $0.0182^{* * *}$ \\
\hline & $(0.00499)$ & $(0.00354)$ & $(0.00429)$ & $(0.00312)$ \\
\hline \multirow[t]{2}{*}{ Internal R\&D intensity } & $0.195^{* * *}$ & -0.000197 & $0.105^{* *}$ & $-0.00273^{* * *}$ \\
\hline & $(0.0656)$ & $(0.00367)$ & $(0.0501)$ & $(0.000954)$ \\
\hline \multirow[t]{2}{*}{ Intangible assets ratio } & $0.157^{* * *}$ & $0.0396^{* * *}$ & $0.118^{* * *}$ & $0.0342^{* * *}$ \\
\hline & $(0.0264)$ & $(0.0127)$ & $(0.0216)$ & $(0.0111)$ \\
\hline \multirow[t]{2}{*}{$\log ($ patent $)$} & $0.00621^{* *}$ & $0.0249^{* * *}$ & $0.00883^{* * *}$ & $0.0222^{* * *}$ \\
\hline & $(0.00298)$ & $(0.00342)$ & $(0.00253)$ & $(0.00285)$ \\
\hline \multirow[t]{2}{*}{ Log(trademark) } & $0.0140^{* * *}$ & 0.00428 & $0.00883^{* * *}$ & 0.00358 \\
\hline & $(0.00299)$ & $(0.00261)$ & $(0.00259)$ & $(0.00224)$ \\
\hline \multirow[t]{2}{*}{ Permanent employee ratio } & -0.0414 & $-0.0546^{* *}$ & 0.0426 & -0.0267 \\
\hline & $(0.0524)$ & $(0.0238)$ & $(0.0470)$ & $(0.0212)$ \\
\hline \multirow[t]{2}{*}{ Outsourcing rate } & 0.0272 & 0.0131 & 0.00468 & $0.0263 * *$ \\
\hline & $(0.0170)$ & $(0.0138)$ & $(0.0124)$ & $(0.0107)$ \\
\hline \multirow[t]{2}{*}{ External R\&D intensity } & -0.502 & 0.0571 & -0.145 & $0.00732 * * *$ \\
\hline & $(0.638)$ & $(0.0701)$ & $(0.368)$ & $(0.00142)$ \\
\hline \multirow[t]{2}{*}{ Parent dummy } & $0.0273^{* *}$ & 0.00151 & 0.0183 * & -0.00213 \\
\hline & $(0.0110)$ & $(0.00883)$ & $(0.00965)$ & $(0.00762)$ \\
\hline \multirow[t]{2}{*}{ Subsidiary dummy } & 0.00940 & $0.0156^{*}$ & 0.00550 & 0.0108 \\
\hline & $(0.00792)$ & $(0.00804)$ & $(0.00674)$ & $(0.00697)$ \\
\hline \multirow[t]{2}{*}{ Alliance dummy } & $0.163^{* * *}$ & $0.220^{* * *}$ & $0.113^{* * *}$ & $0.157^{* * *}$ \\
\hline & $(0.0204)$ & $(0.0195)$ & $(0.0174)$ & $(0.0168)$ \\
\hline \multirow[t]{2}{*}{ Foreigners' share } & -0.00439 & -0.00135 & -0.0138 & -0.00382 \\
\hline & $(0.0155)$ & $(0.0140)$ & $(0.0138)$ & $(0.0125)$ \\
\hline \multirow[t]{2}{*}{ Profitability } & $0.0838^{* * *}$ & 0.000651 & 0.0390 & -0.0000104 \\
\hline & $(0.0303)$ & $(0.00182)$ & $(0.0242)$ & $(0.000117)$ \\
\hline \multirow[t]{2}{*}{ Debt ratio } & 0.0149 & 0.00216 & 0.00414 & -0.00330 \\
\hline & $(0.0101)$ & $(0.00310)$ & $(0.00948)$ & $(0.00392)$ \\
\hline Observations & 6120 & 6537 & 6072 & 6328 \\
\hline Log-likelihood & -1708.2 & -1828.5 & -1316.4 & -1394.2 \\
\hline chi-squared & 549.9 & 1108.7 & 486.9 & 961.1 \\
\hline
\end{tabular}

$* * * p<0.01,{ }^{* *} p<0.05, * p<0.1$

Affiliation with a parent company and strategic alliances prompt manufacturing firms to adopt new technology. In contrast, owning subsidiaries and having strategic alliances induce service firms to adopt the technology. Interestingly, a higher share of permanent employees in the workforce negatively affects service firms' propensity for adopting the technology. This indicates that the flexibility of the workforce may be an important factor in adopting technology in the service sector. The significant association of strategic alliances with the propensity for adopting technology implies that cooperation with external agencies enhances the motivation for adopting technology, and its coefficient is the largest. Finally, profitability is a positive factor in technology adoption only for manufacturing firms.

The next two columns of Table 2 present marginal effects from the probit estimation of the development of the Fourth Industrial Revolution technologies. Like adoption, the development of technology is positively associated with firm size. In the manufacturing sector, firms with intensive internal R\&D investment, intensive intangible assets, and intellectual property rights are more likely to develop advanced technology by themselves. However, in the service sector, only intensive intangible assets and patent rights are positively associated with the propensity for developing technology.

Again, a strong association is found between strategic alliances and the propensity for technology development, and the coefficient is larger for service firms. The coefficient on external R\&D intensity is significantly positive for service firms, whereas the coefficient on 
internal R\&D intensity is significantly positive for manufacturing firms. In sum, the probit estimation of technology development again exhibits sectoral differences in the capability, and cumulative dynamics of developing new technologies, and particularly service firms are more reliant on cooperation with external agencies for technology development.

\subsection{Robustness Check: Subsector Estimations}

This subsection examines the propensity for technology adoption and development for subsectors in the manufacturing and service sectors. To examine the determinants of technology adoption (usage) and development further, manufacturing is separated into high-tech and non-high-tech industries based on the Korea Standard Industry Categorization (KSIC), ninth revision. The list of high-tech industries in this study includes "chemicals and chemical products except for pharmaceutical, medicinal" (industry code 20); "pharmaceuticals, medicinal chemicals, and botanical products" (industry code 21); "electronic components, computer, radio, and television and communication equipment and apparatuses" (industry code 26); "medical, precision, and optical instruments, watches, and clocks" (industry code 27); "electrical equipment" (industry code 28); and "motor vehicles, trailers, and semitrailers"(industry code 30).

The service industry is also categorized into distribution, producer, and individual service sectors. The distribution service sector includes "wholesale trade" (industry code 46), "retail trade, except motor vehicles and motorcycles" (industry code 47), and "transport and storage" (industry codes 49-52). The producer service sector includes "publishing activities" (industry code 58); "broadcasting activities" (industry code 60); "postal activities and telecommunication" (industry code 61); "computer programming, consultancy and related activities" (industry code 62); "information service" (industry code 63); "real estate activities" (industry code 68); and "professional, scientific and technical activities" (industry codes 70-73). Finally, the individual service sector involves "accommodation and food service activities" (industry codes 55,56 ). The social service sector involving health care and education is not included in this study due to a lack of observations of the most relevant variables.

For instance, the probit estimation in Table 2 shows that R\&D investment is an important factor in technology adoption and development. Table 3 shows that R\&D expenditures are concentrated in the high-tech manufacturing sector and the producer service sector. Considering this concentrated distribution of $R \& D$ expenditures to a limited sector and the importance of R\&D capability, the probit estimations were additionally performed for the subsectors of the manufacturing and service sectors.

Table 3. R\&D expenditures in Korea (sectoral aggregates) ${ }^{1}$.

\begin{tabular}{cccccc}
\hline Industry & $\mathbf{2 0 1 4}$ & $\mathbf{2 0 1 5}$ & $\mathbf{2 0 1 6}$ & $\mathbf{2 0 1 7}$ & $\mathbf{2 0 1 8}$ \\
\hline All industries & $49,854,465$ & $51,136,421$ & $53,952,471$ & $62,563,447$ & $68,834,432$ \\
Manufacturing & $44,328,185$ & $45,822,445$ & $47,884,170$ & $55,843,296$ & $61,00,8786$ \\
(Share, \%) & $(88.9 \%)$ & $(89.6 \%)$ & $(88.8 \%)$ & $(89.3 \%)$ & $(88.6 \%)$ \\
High-tech & $23,959,606$ & $23,843,865$ & $25,424,001$ & $30,209,827$ & $33,494,314$ \\
(Share, \%) & $(48.1 \%)$ & $(46.6 \%)$ & $(47.1 \%)$ & $(48.3 \%)$ & $(48.7 \%)$ \\
Service & $4,117,161$ & $4,117,377$ & $4,665,445$ & $5,220,731$ & $6,234,861$ \\
(Share, \%) & $(8.3 \%)$ & $(8.1 \%)$ & $(8.6 \%)$ & $(8.3 \%)$ & $(9.1 \%)$ \\
Distribution & 787,880 & 658,937 & 709,006 & 797,288 & $1,077,425$ \\
(Share, \%) & $(1.6 \%)$ & $(1.3 \%)$ & $(1.3 \%)$ & $(1.3 \%)$ & $(1.6 \%)$ \\
Producer & $3,284,633$ & $3,399,793$ & $3,855,702$ & $4,301,456$ & $5,007,870$ \\
(Share, \%) & $(6.6 \%)$ & $(6.6 \%)$ & $(7.1 \%)$ & $(6.9 \%)$ & $(7.3 \%)$ \\
Individual & 25,635 & 29,577 & 66,161 & 72,283 & 84,585 \\
(Share, \%) & $(0.1 \%)$ & $(0.1 \%)$ & $(0.1 \%)$ & $(0.1 \%)$ & $(0.1 \%)$ \\
\hline
\end{tabular}

${ }^{1}$ Measure of R\&D expenditures is 1 million Korean won. Shares calculated by the author. Data: Korea INSTANS database (source: https: / /istans.or.kr, downloaded 8 November 2020) 
Table 4 shows the results from the probit estimations for high-tech and non-high-tech manufacturing industries. The propensity for adopting the Fourth Industrial Revolution technology is positively associated with firm size. It is also positively associated with internal R\&D intensity, intangible assets ratio, trademarks, and strategic alliances in both sectors, and the coefficients are substantially larger for the high-tech sector than the nonhigh-tech sector. Affiliation with a parent company is positively associated with the propensity for only the non-high-tech sector.

Table 4. Probit estimation marginal effects: high-tech and non-high-tech manufacturing.

\begin{tabular}{|c|c|c|c|c|}
\hline & \multicolumn{2}{|c|}{ Adoption } & \multicolumn{2}{|c|}{ Development } \\
\hline & (1) & $(2)$ & (3) & (4) \\
\hline & High-Tech & Non-High-Tech & High-Tech & Non-High-Tech \\
\hline \multirow[t]{2}{*}{ Log(employment) } & $0.0370 * *$ & $0.0270 * * *$ & 0.0199 & $0.0200^{* * *}$ \\
\hline & $(0.0153)$ & $(0.00510)$ & $(0.0139)$ & $(0.00427)$ \\
\hline \multirow[t]{2}{*}{ Internal R\&D intensity } & $0.618^{* * *}$ & $0.143 *$ & $0.445^{* * *}$ & 0.0548 \\
\hline & $(0.170)$ & $(0.0756)$ & $(0.145)$ & $(0.0585)$ \\
\hline \multirow[t]{2}{*}{ Intangible asset ratio } & $0.221^{* * *}$ & $0.131^{* * *}$ & $0.181^{* * *}$ & $0.0979 * * *$ \\
\hline & $(0.0553)$ & $(0.0337)$ & $(0.0491)$ & $(0.0272)$ \\
\hline \multirow[t]{2}{*}{$\log ($ patent $)$} & 0.00946 & 0.00475 & $0.0153 *$ & $0.00702^{* * *}$ \\
\hline & $(0.00911)$ & $(0.00304)$ & $(0.00819)$ & $(0.00251)$ \\
\hline \multirow[t]{2}{*}{ Log(trademark) } & $0.0222 * *$ & $0.0122 * * *$ & 0.0134 & $0.00734^{* * *}$ \\
\hline & $(0.00967)$ & $(0.00299)$ & $(0.00911)$ & $(0.00247)$ \\
\hline \multirow[t]{2}{*}{ Permanent employee ratio } & 0.135 & -0.0560 & 0.171 & 0.0260 \\
\hline & $(0.225)$ & $(0.0472)$ & $(0.193)$ & $(0.0417)$ \\
\hline \multirow[t]{2}{*}{ Outsourcing rate } & -0.00153 & 0.0265 & 0.0151 & 0.00296 \\
\hline & $(0.0676)$ & $(0.0167)$ & $(0.0601)$ & $(0.0117)$ \\
\hline \multirow[t]{2}{*}{ External R\&D intensity } & -1.347 & -0.474 & -0.612 & -0.478 \\
\hline & $(0.957)$ & $(1.276)$ & $(0.756)$ & $(1.084)$ \\
\hline \multirow[t]{2}{*}{ Parent dummy } & 0.0364 & $0.0254^{* *}$ & 0.0236 & $0.0168 *$ \\
\hline & $(0.0351)$ & $(0.0111)$ & $(0.0330)$ & $(0.00937)$ \\
\hline \multirow[t]{2}{*}{ Subsidiary dummy } & 0.0171 & 0.00734 & 0.0240 & 0.00109 \\
\hline & $(0.0248)$ & $(0.00807)$ & $(0.0225)$ & $(0.00668)$ \\
\hline \multirow[t]{2}{*}{ Alliance dummy } & $0.227^{* * *}$ & $0.147^{* * *}$ & $0.197^{* * *}$ & $0.0917^{* * *}$ \\
\hline & $(0.0470)$ & $(0.0228)$ & $(0.0457)$ & $(0.0186)$ \\
\hline \multirow[t]{2}{*}{ Foreigners' share } & 0.00854 & -0.00734 & 0.0194 & -0.0207 \\
\hline & $(0.0462)$ & $(0.0159)$ & $(0.0435)$ & $(0.0141)$ \\
\hline \multirow[t]{2}{*}{ Profitability } & 0.0849 & 0.0793 * & 0.0526 & 0.0290 \\
\hline & $(0.0533)$ & $(0.0420)$ & $(0.0460)$ & $(0.0331)$ \\
\hline \multirow[t]{2}{*}{ Debt ratio } & 0.0213 & 0.0133 & 0.0180 & -0.00236 \\
\hline & $(0.0218)$ & $(0.0126)$ & $(0.0206)$ & $(0.0115)$ \\
\hline Observations & 1110 & 5010 & 1110 & 4962 \\
\hline Log-likelihood & -450.7 & -1251.9 & -392.4 & -918.0 \\
\hline chi-squared & 135.8 & 352.5 & 113.5 & 301.5 \\
\hline
\end{tabular}

$\overline{* * *} p<0.01,{ }^{* *} p<0.05,{ }^{*} p<0.1$.

The third and fourth columns of Table 4 demonstrate that the propensity for technology development is positively associated with internal R\&D intensity only for high-tech firms and not for non-high-tech firms. In contrast to the propensity for adoption, patent rights are positively associated with the propensity for development of technology, and the association is stronger for high-tech firms. While trademark rights are positively significant only for non-high-tech firms, the coefficient on the intangible asset ratio is also larger for high-tech firms. Strategic alliance is again an important factor for the development of the Fourth Industrial Revolution technology. Therefore, high-tech firms are substantially dependent on capability as internal R\&D investment and intangible assets, but also strategic alliance to adopt and develop the Fourth Industrial Revolution technology.

Table 5 shows the probit estimation results on the service subsectors. The first three columns show the results of the propensity for adopting the Fourth Industrial Revolution technology, and the next three columns display the results on the propensity for developing 
the technology. The propensity for adopting technology is associated with firm size in all subsectors. The distribution service sector shows a positive association of internal R\&D intensity and intangible assets ratio with this propensity, whereas the distribution and producer service sectors show a positive effect of patent rights. A high ratio of permanent employees negatively affects this propensity in the producer and individual service sectors, implying that workforce flexibility within a firm could be a favorable factor in adopting the technology. Affiliation with a parent company displays mixing results on distribution service and producer service firms since it is positively (negatively) associated with the propensity for adopting technology in distribution (producer) service firms. Furthermore, the positive effects of strategic alliances are significant only in distribution and producer service firms, while the significantly positive impact of profitability is observed in individual service firms.

Table 5. Probit estimation marginal effects: service subsectors.

\begin{tabular}{|c|c|c|c|c|c|c|}
\hline & \multicolumn{3}{|c|}{ Adoption } & \multicolumn{3}{|c|}{ Development } \\
\hline & (1) & (2) & (3) & (4) & (5) & (6) \\
\hline & Distribution & Producer & Individual & Distribution & Producer & Individual \\
\hline \multirow[t]{2}{*}{ Log(employment) } & $0.0147^{* * *}$ & $0.0423 * * *$ & $0.0362 * * *$ & 0.00547 & $0.0292 * * *$ & $0.0211^{* * *}$ \\
\hline & $(0.00494)$ & $(0.00864)$ & $(0.00973)$ & $(0.00393)$ & $(0.00797)$ & $(0.00710)$ \\
\hline \multirow[t]{2}{*}{ Internal R\&D intensity } & $0.198 *$ & 0.00625 & -0.391 & $0.174^{* *}$ & -0.00687 & 1.455 \\
\hline & $(0.110)$ & $(0.00665)$ & $(4.075)$ & $(0.0806)$ & $(0.00899)$ & $(2.022)$ \\
\hline \multirow[t]{2}{*}{ Intangible asset ratio } & $0.0491 * *$ & 0.0373 & $-0.121 *$ & $0.0355 * *$ & 0.0186 & $-0.0881 *$ \\
\hline & $(0.0209)$ & $(0.0255)$ & $(0.0699)$ & $(0.0159)$ & $(0.0236)$ & $(0.0483)$ \\
\hline \multirow[t]{2}{*}{$\log ($ patent $)$} & $0.0272^{* * *}$ & $0.0383^{* * *}$ & 0.00638 & $0.0182^{* * *}$ & $0.0370^{* * *}$ & -0.0207 \\
\hline & $(0.00615)$ & $(0.00736)$ & $(0.0179)$ & $(0.00463)$ & $(0.00647)$ & $(0.0144)$ \\
\hline \multirow[t]{2}{*}{ Log(trademark) } & 0.00262 & -0.00393 & -0.0100 & 0.00440 & -0.00375 & -0.00209 \\
\hline & $(0.00365)$ & $(0.00667)$ & $(0.00710)$ & $(0.00269)$ & $(0.00612)$ & $(0.00482)$ \\
\hline \multirow[t]{2}{*}{ Permanent employee ratio } & -0.0519 & $-0.220 * *$ & $-0.134^{* *}$ & -0.0196 & $-0.160 *$ & -0.0661 \\
\hline & $(0.0545)$ & $(0.0948)$ & $(0.0609)$ & $(0.0357)$ & $(0.0893)$ & $(0.0470)$ \\
\hline \multirow[t]{2}{*}{ Outsourcing rate } & 0.0178 & -0.0291 & -0.0963 & 0.0173 & 0.0396 & 0.0241 \\
\hline & $(0.0179)$ & $(0.0334)$ & $(0.150)$ & $(0.0131)$ & $(0.0380)$ & $(0.0307)$ \\
\hline \multirow[t]{2}{*}{ External R\&D intensity } & 0.0409 & 0.0810 & - & -0.0574 & $0.0127^{* * *}$ & - \\
\hline & $(0.290)$ & $(0.106)$ & - & $(0.187)$ & $(0.00288)$ & - \\
\hline \multirow[t]{2}{*}{ Parent dummy } & $0.0423 * * *$ & $-0.0591^{* * *}$ & 0.00928 & $0.0201 *$ & $-0.0347 *$ & -0.0185 \\
\hline & $(0.0156)$ & $(0.0206)$ & $(0.0247)$ & $(0.0112)$ & $(0.0189)$ & $(0.0153)$ \\
\hline \multirow[t]{2}{*}{ Subsidiary dummy } & 0.0134 & 0.0243 & -0.00392 & 0.00694 & 0.0106 & 0.0102 \\
\hline & $(0.0124)$ & $(0.0188)$ & $(0.0153)$ & $(0.00963)$ & $(0.0170)$ & $(0.0130)$ \\
\hline \multirow[t]{2}{*}{ Alliance dummy } & $0.165^{* * *}$ & $0.292^{* * *}$ & 0.0794 & $0.153^{* * *}$ & $0.196^{* * *}$ & 0.0614 \\
\hline & $(0.0372)$ & $(0.0329)$ & $(0.0656)$ & $(0.0338)$ & $(0.0299)$ & $(0.0477)$ \\
\hline \multirow[t]{2}{*}{ Foreigners' share } & -0.0255 & $0.0669 *$ & 0.0156 & -0.00842 & 0.00856 & $0.0462 * *$ \\
\hline & $(0.0178)$ & $(0.0390)$ & $(0.0333)$ & $(0.0138)$ & $(0.0377)$ & $(0.0230)$ \\
\hline \multirow[t]{2}{*}{ Profitability } & 0.00521 & 0.00265 & $0.177 *$ & 0.00357 & -0.00137 & $0.137^{* *}$ \\
\hline & $(0.00328)$ & $(0.00285)$ & $(0.0906)$ & $(0.00241)$ & $(0.00339)$ & $(0.0676)$ \\
\hline \multirow[t]{2}{*}{ Debt ratio } & 0.00621 & -0.0000308 & 0.00800 & 0.00153 & $-0.0199 *$ & $0.00769 * *$ \\
\hline & $(0.00401)$ & $(0.00574)$ & $(0.00520)$ & $(0.00362)$ & $(0.0110)$ & $(0.00360)$ \\
\hline Observations & 2114 & 1862 & 336 & 2114 & 1862 & 336 \\
\hline Log-likelihood & -468.3 & -786.7 & -43.9 & -327.7 & -667.6 & -27.4 \\
\hline chi-squared & 176.8 & 396.2 & 32.2 & 166.5 & 337.1 & 41.6 \\
\hline
\end{tabular}

When it comes to the propensity for developing technology, in the last three columns in Table 5, most results are consistent with the results on adopting the technology. External R\&D intensity is found to be positively associated with the propensity for developing technology in the producer service sector. Because this sector is the largest spender on $R \& D$ among the service sectors, this result may imply that service firms' dependence on external R\&D to develop advanced technology in Table 2 is driven by the producer service firms. Finally, a strategic alliance is a substantially positive factor in the propensity for 
developing the Fourth Industrial Revolution technology. This subsector estimation reflects that determinants of technology adoption and development are dependent on sectoral characteristics in addition to firm-specific characteristics.

\section{Discussion and Concluding Remarks}

Using firm-level data from the Survey of Business Activities in 2018, this study examined the propensity for adopting and developing the Fourth Industrial Revolution technology, including IoT, cloud computing, big data, 5G mobile technology, artificial intelligence, blockchain, 3D printing, robotics, and virtual/augmented reality. Probit methodology was applied, and estimations found size effects on the likelihood of innovative investment for the Fourth Industrial Revolution technology in general. The size effects are consistent with the size effects on R\&D investment $[34,36]$. Thus, the empirical results imply that larger firms are slightly more likely to adopt or develop the Fourth Industrial Revolution technology than smaller firms.

The main estimation results are summarized as follows: In the manufacturing sector, internal R\&D intensity, intangible assets ratio, and patent and trademark rights are positively associated with the propensity for adopting and developing technology; in the service sector, intangible assets ratio and patent rights are positive factors to the propensity. For both sectors, a strategic alliance is found to be substantially significant to the propensity for adoption and development.

Specifically, the positive association of internal R\&D intensity with the likelihood of technology adoption and development in the manufacturing sector suggests that internal R\&D activities reflect the firm-level capability of technological innovation. This contrasts with the lack of such relationships in the service sector, where innovation is rather "soft" and not necessarily limited to formal R\&D activities [53,54].

The significance of the intangible assets ratio and patent rights indicates the importance of cumulative dynamics within the firm. In other words, firms with more intangible assets and patent rights are more likely to use or develop advanced technology. Since intangible assets are closely related to firm performance [31,32], firms with a higher share of intangible assets may be more open to adopting or developing advanced technology, eventually more likely to innovate and succeed. On the other hand, only patent rights are significant to technology adoption and development in both the manufacturing and service sector, and this reflects that internally cumulated knowledge in the form of patent rights is most relevant to technical capability. This result confirms the technical property of the Fourth Industrial Revolution and suggests an advantage to firms with accumulated technical knowledge. Thus, this finding is also consistent with the previous findings of the positive role of cumulative dynamics on innovation [34,55,56].

Among within-firm organizational factors, employment flexibility in the service sector stands out, whereas other affiliations or ownership variables do not present a consistent conclusion. The negative coefficient on the permanent employee ratio is interpreted that service firms with less permanent employees are likely to adopt and develop the Fourth Industrial Revolution technology. Since the Fourth Industrial Revolution, technology is considered to have an enormously disruptive impact on the stability of employment $[3,57]$. Service firms with fewer permanent employees are likely to adopt advanced technology and adjust organizational structure flexibly. In contrast, a potential explanation of why no such result is found from the manufacturing sector is that Korean manufacturing firms have already been automated to a high degree. According to the International Federation of Robotics, robot density in the Korean manufacturing sector was 855 units of robots installed per 10,000 employees in 2019, next to Singapore's 918 units and much higher than the world average of 113 units per 10,000 employees (International Federation of Robotics, link: https: / /ifr.org/ifr-press-releases/news/record-2.7-million-robots-workin-factories-around-the-globe). In other words, Korean manufacturing firms may have already adjusted their employment structure to technological change. 
It is the substantial effect of strategic alliance on technology adoption and development, which should be an interesting route for the diffusion of the Fourth Industrial Revolution. The significant effect of strategic alliance is related to previous studies on R\&D alliance and knowledge spillover [44], even though the contribution of extramural R\&D [57] is only partially found from the estimation. Since the strategic alliance includes technological alliance, marketing and branding alliance, and also co-production alliance, the finding suggests that various types of collaboration with other firms, not limited to R\&D cooperation, can provide incentive and external capability to use or develop the Fourth Industrial Revolution technology. Therefore, it can be concluded that collaboration plays a significant role in the diffusion of the Fourth Industrial Revolution.

In conclusion, this study specifies the determinants of adoption and development of the Fourth Industrial Revolution technology, which has been documented not much, compared to similar studies on R\&D investment or intangible capital accumulation [34,58-60]. Partially this is due to the relative novelty of the Fourth Industrial Revolution technology, but also due to the limited availability of data. From this perspective, the Survey of Business Activities allows researchers to examine the decision of technology adoption and development within the whole economy. This study contributes to the existing literature by emphasizing interfirm organizational factors like strategic alliance, which is found to be more influential than capability, cumulative dynamics, or within-firm organizational factors.

This result presents an important implication to an economy like Korea, which invests intensively in R\&D and intangible assets, but its growth performance has weakened, as pointed out in the introduction. Possibly efficiency of R\&D and intangible assets has diminished or become less innovative; thus, the Korean economy needs to revitalize the economy by improving the effectiveness of R\&D and intangibles. In addition to intensifying $R \& D$ and intangible assets, the expansion of various collaborations between firms could be an effective alternative to facilitate innovation. It is even more so if we consider the rising importance of convergence in the Fourth Industrial Revolution. This result also could be relevant with the study of small- and medium-sized enterprises (SMEs) innovation performance $[40,61,62]$, since their size can limit their capability to adopt or develop the Fourth Industrial Revolution technology.

However, the findings from this study are not without limitations. At this point, only one-year data are available, so it is not possible to use a panel analysis methodology that could mitigate the potential concern of simultaneity and endogeneity. Furthermore, it is necessary to examine in the future study if a specific type of strategic alliance has differential effects on the Fourth Industrial Revolution technology adoption and development. In addition, the Survey of Business Activities is not ideal for analyzing the contribution of a strategic alliance by SMEs because the sample does not include small firms. Therefore, analysis of strategic alliances by SMEs would require an alternative database in the future.

Funding: This research received no external funding.

Institutional Review Board Statement: Not applicable.

Informed Consent Statement: Not applicable.

Data Availability Statement: Data is available only to the institution with paid subscription.

Acknowledgments: I appreciate comments from anonymous referees.

Conflicts of Interest: The author declares no conflict of interest.

\section{References}

1. Klitou, D.; Conrads, J.; Rasmussen, M.; Probst, L.; Pedersen, B. Digital Transformation Monitor: Germany Industrie 4.0. European Commission. 2017. Available online: https://ec.europa.eu/growth/tools-databases/dem/monitor/sites/default/files/DTM_ Industrie\%204.0.pdf (accessed on 29 December 2020).

2. Schwab, K. The Fourth Industrial Revolution; World Economic Forum: Cologny, Switzerland, 2016.

3. World Economic Forum. Readiness for the Future of Production Report 2018; World Economic Forum: Cologny, Switzerland, 2018. 
4. Jamrisko, M.; Lu, W. Germany Breaks Korea's Six-Year Streak as Most Innovative Nation. Bloomberg. 2019. Available online: https: //www.bloombergquint.com/global-economics/germany-breaks-korea-s-six-year-streak-as-most-innovative-nation (accessed on 7 December 2020).

5. Chakravorti, B.; Chaturvedi, R.S. Digital Planet 2017: How Competitiveness and Trust in Digital Economies Vary across the World; The Fletcher School Tufts University: Medford, MA, USA, 2017.

6. Cornell Univeristy; INSEAD. Global Innovation Index 2020: Who Will Finance Innovation? World Intellectual Property Organization: Geneva, Switzerland, 2020.

7. Sung, T.K. Industry 4.0: A Korea perspective. Technol. Soc. Chang. 2018, 132, 40-45. [CrossRef]

8. Bartodziej, C.J. The Concept Industry 4.0; Springer Gabler: Wiesbaden, Germany, 2017.

9. Vaidya, S.; Ambad, P.; Bhosle, S. Industry 4.0-A Glimpse. Procedia Manuf. 2018, 20, 233-238. [CrossRef]

10. Davis, N. What is the Fourth Industrial Revolution? Available online: https://www.weforum.org/agenda/2016/01/what-is-thefourth-industrial-revolution/ (accessed on 7 December 2020).

11. KISDI. A Study on the National Policy Agenda Based on Science E Technology, ICT for Leading the 4th Industrial Revolution; Korea Information Society Development Institute: Deoksan-myeon, Korea, 2017.

12. Vandermerwe, S.; Rada, J. Servitization of Business: Adding Value by Adding Services. Eur. Manag. J. 1988, 6, 314. [CrossRef]

13. Taddy, M. The Technological Elements of Artificial Intelligence. In The Economics of Artificial Intelligence; University of Chicago Press: Chicago, IL, USA, 2019.

14. OECD. The Next Production Revolution: Implications for Governments and Business; OECD Publishing: Paris, France, 2017.

15. Brynjolfsson, E.; McAfee, A. The Second Machine Age: Work, Progress, and Prosperity in a Time of Brilliant Technologies; Norton: New York, NY, USA, 2014.

16. Schwab, K. The Fourth Industrial Revolution: What It Means and How to Respond. Foreign Affairs. 2015. Available online: https:/ / www.foreignaffairs.com/articles/2015-12-12/fourth-industrial-revolution (accessed on 7 December 2020).

17. Xu, M.; David, J.M.; Kim, S.H. The Fourth Industrial Revolution: Opportunities and Challenges. Int. J. Financ. Res. 2018, 9, 90. [CrossRef]

18. Chen, N.; Christensen, L.; Gallagher, K.; Mate, R.; Rafert, G. Global Economic Impacts Associated with Artificial Intelligence. 2016. Available online: https://www.analysisgroup.com/globalassets/content/insights/publishing/ag_full_report_economic_ impact_of_ai.pdf (accessed on 6 December 2020).

19. Kim, G.; Lee, H.; Kim, J.; Kwon, H.J. The Fourth Industrial Revolution in Major Countries and Its Implications of Korea: U.S., Germany and Japan Cases. World Economy Brief 18-20. 2018. Available online: https://papers.ssrn.com/sol3/papers.cfm? abstract_id=3304923 (accessed on 16 January 2021).

20. Oulton, N. ICT and Productivity Growth in the United Kingdom. Oxf. Rev. Econ. Policy 2002, 18, 363-379. [CrossRef]

21. Colecchia, A.; Schreyer, P. ICT Investment and Economic Growth in the 1990s: Is the United States a Unique Case? A Comparative Study of Nine OECD Countries. Rev. Econ. Dyn. 2002, 5, 408-442. [CrossRef]

22. Corrado, C.; Haskel, J.; Jona-Lasinio, C. Knowledge Spillovers, ICT and Productivity Growth. Oxf. Bull. Econ. Stat. 2017, 79, 592-618. [CrossRef]

23. Guerrieri, P.; Luciani, M.; Meliciani, V. The determinants of investment in information and communication technologies. Econ. Innov. New Technol. 2011, 20, 387-403. [CrossRef]

24. Haller, S.A.; Siedschlag, I. Determinants of ICT adoption: Evidence from firm-level data. Appl. Econ. 2011, 43, 3775-3788. [CrossRef]

25. Aghion, P.; Howitt, P. Endogenous Growth Theory; MIT Press: Cambridge, MA, USA, 1998.

26. Aghion, P.; Howitt, P. A Model of Growth Through Creative Destruction. Econometrica 1992, 60, 323-351. [CrossRef]

27. OECD. Supporting Investment in Knowledge Capital, Growth and Innovation; OECD: Paris, France, 2013.

28. Haskel, J.; Westlake, S. Capitalism without Capital; Princeton University Press: Princeton, NJ, USA, 2017.

29. Sichel, D.; Hulten, C.; Corrado, C. Measuring Capital and Technology: An Expanded Framework. In Measuring Capital in the New Economy; University of Chicago Press: Chicago, IL, USA, 2005.

30. Corrado, C.; Haskel, J.; Jona-Lasinio, C.; Iommi, M. Innovation and intangible investment in Europe, Japan, and the United States. Oxf. Rev. Econ. Policy 2013, 29, 261-286. [CrossRef]

31. Chappell, N.; Jaffe, A. Intangible Investment and Firm Performance. Rev. Ind. Organ. 2018, 52, 509-559. [CrossRef]

32. Bontempi, M.E.; Mairesse, J. Intangible capital and productivity at the firm level: A panel data assessment. Econ. Innov. New Technol. Prod. Netw. Knowl. Flows 2015, 24, 22-51. [CrossRef]

33. Hulten, C.R.; Hao, J.X. What is a Company Really Worth? Intangible Capital and the "Market to Book Value" Puzzle. Natl. Bur. Econ. Res. 2008. [CrossRef]

34. Arrighetti, A.; Landini, F.; Lasagni, A. Intangible assets and firm heterogeneity: Evidence from Italy. Res. Policy 2014, 43, 202-213. [CrossRef]

35. Shefer, D.; Frenkel, A. R\&D, firm size and innovation: An empirical analysis. Technovation 2005, 25, 25-32.

36. Cohen, W.M.; Klepper, S. Firm Size and the Nature of Innovation within Industries: The Case of Process and Product R\&D. Rev. Econ. Stat. 1996, 78, 232-243.

37. Dosi, G.; Nelson, R.; Winter, S. The Nature and Dynamics of Organizational Capabilities; Oxford University Press: Oxford, UK, 2001. 
38. Brynjolfsson, E.; Hitt, L.M.; Yang, S. Intangible Assets: Computers and Organizational Capital. Brook. Pap. Econ. Act. 2002, 2002, 137-198. [CrossRef]

39. Radhakrishnan, S.; Lev, B. The Measurement of Firm-Specific Organization Capital. Natl. Bur. Econ. Res. 2003. [CrossRef]

40. Chun, H.; Mun, S. Determinants of R\&D cooperation in small and medium-sized enterprises. Small Bus. Econ. 2012, 39, 419-436.

41. Belderbos, R.; Carree, M.; Lokshin, B. Cooperative R\&D and firm performance. Res. Policy 2004, 33, $1477-1492$.

42. Belderbos, R.; Carree, M.; Lokshin, B. Complementarity in R\&D Cooperation Strategies. Rev. Ind. Organ. 2006, 28, 401-426.

43. Sampson, R.C. R\&D Alliances and Firm Performance: The Impact of Technological Diversity and Alliance Organization on Innovation. Acad. Manag. J. 2007, 50, 364-386.

44. Lin, W.B. Factors affecting the correlation between interactive mechanism of strategic alliance and technological knowledge transfer performance. J. High Technol. Manag. Res. 2007, 17, 139-155. [CrossRef]

45. Lin, Z.; Yang, H.; Arya, B. Alliance partners and firm performance: Resource complementarity and status association. Strat. Manag. J. 2009, 30, 921-940. [CrossRef]

46. Hall, B.H.; Lerner, J. The Financing of R\&D and Innovation. In Handbook of the Economics of Innovation; Hall, B.H., Rosenberg, N., Eds.; Elsevier: Amsterdam, The Netherlands, 2010; Volume 1, pp. 609-639.

47. Hall, B.H.; Moncada-Paterno-Castello, P.; Montresor, S. Financing Constraints, R\&D investments and Innovative Performances: New Empirical Evidence at the Firm Level for Europe. Econ. Innov. New Technol. 2016, 25, 183-196.

48. Brown, J.R.; Martinsson, G.; Petersen, B.C. Do financing constraints matter for R\&D? Eur. Econ. Rev. 2012, 56, $1512-1529$.

49. Hall, B.H. The Financing of Research and Development. Oxf. Rev. Econ. Policy 2002, 18, 35-51. [CrossRef]

50. Brown, J.R.; Petersen, B.C. Cash holdings and R\&D smoothing. J. Corp. Financ. 2011, 17, 694-709.

51. Brown, J.R.; Fazzari, S.M.; Petersen, B.C. Financing Innovation and Growth: Cash Flow, External Equity, and the 1990s R\&D Boom. J. Financ. 2009, 64, 151-185.

52. Czarnitzki, D.; Hottenrott, H. Financial Constraints: Routine Versus Cutting Edge R\&D Investment. J. Econ. Manag. Strategy 2011, 20,121-157.

53. Tether, B.S. Do Services Innovate (Differently)? Insights from the European Innobarometer Survey. Ind. Innov. Innov. Serv. 2005, 12, 153-184. [CrossRef]

54. Tingvall, P.G.; Karpaty, P. Service-sector competition, innovation and R\&D. Econ. Innov. New Technol. 2011, $20,63-88$.

55. Ocak, M.; Findık, D. The Impact of Intangible Assets and Sub-Components of Intangible Assets on Sustainable Growth and Firm Value: Evidence from Turkish Listed Firms. Sustainability 2019, 11, 5359. [CrossRef]

56. Niebel, T.; O'Mahony, M.; Saam, M. The Contribution of Intangible Assets to Sectoral Productivity Growth in the EU. Rev. Income Wealth 2017, 63, S49-S67. [CrossRef]

57. Jha, A.K.; Bose, I. Innovation in IT firms: An investigation of intramural and extramural R\&D activities and their impact. Inf. Manag. 2016, 53, 409-421.

58. Peters, B. Persistence of innovation: Stylised facts and panel data evidence. J. Technol. Transf. 2007, 34, 226-243. [CrossRef]

59. Yang, S.; Zhou, Y.; Song, L. Determinants of Intangible Investment and Its Impacts on Firms' Productivity: Evidence from Chinese Private Manufacturing Firms. China World Econ. 2018, 26, 1-26. [CrossRef]

60. Máñez, J.A.; Rochina-Barrachina, M.E.; Sanchis, A.; Sanchis, J.A. The Role of Sunk Costs in the Decision to Invest in R\&D. J. Ind. Econ. 2009, 57, 712-735.

61. Czarnitzki, D. Research and Development in Small and Medium-Sized Enterprises: The Role of Financial Constraints and Public Funding. Scott. J. Political Econ. 2006, 53, 335-357. [CrossRef]

62. Jung, H.; Hwang, J.; Kim, B. Does R\&D investment increase SME survival during a recession? Technol. Forecast. Soc. Chang. 2018, 137, 190-198. 